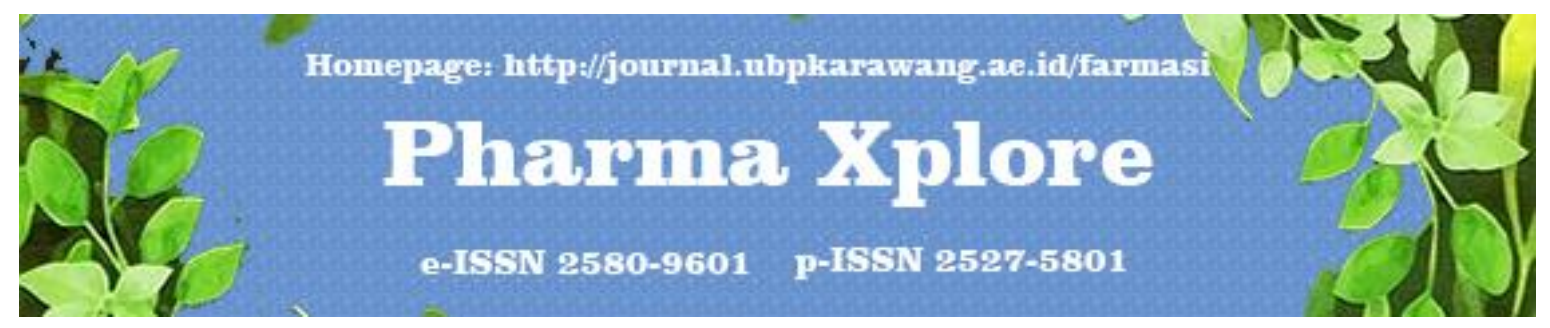

\title{
ISOLASI METABOLIT SEKUNDER FLAVONOID DARI BATANG RANDU (Ceiba pentandra L.)
}

Lia Fikayuniar*,Ermi Abriyani, Wahyu Nur Februrohman

Program Studi Farmasi, Fakultas Farmasi, Universitas Buana Perjuangan, Karawang,

*Penulis korespondensi: lia.fikayuniar@ubpkarawang.ac.id

\begin{abstract}
ABSTRAK
Batang randu adalah pohon tropis yang tergolong ordo Malvaceae (sebelumnya Bombacaceae). Kata 'kapuk' digunakan untuk menyebut serat yang dihasilkan dari bijinya.Pohon ini juga dikenal sebagai Kapas Jawa atau Kapok Jawa. Selama ini batang kapuk randu hanya digunakan sebagai tanaman atau obat herbal tanpa diolah terlebih dahulu. Untuk memberikan informasi mengenai metabolit sekunder yangterkandung pada batang randuCeiba pentandra (L) Gaetrn. Metode yang digunakan yaitu dengan kromatografi lapis tipis yang di lanjut dengan kromatografi kolom. Analisis metabolit sekunder dengan spektrofotometri UV-Vis dengan panjang gelombang 200-600 nm. Hasil penelitian, dapat disimpulkan bahwa pada batang randu Ceiba pentandra (L) Gaetrn Mengandung senyawa flavonoid dengan jenis Flavon.
\end{abstract}

Kata Kunci: Kromatografi Lapis Tipis, Kromatografi Kolom, Batang randu, Spektofotometri UV-Vis

\section{SECONDARY METABOLITE ISOLATION OF FLAVONOID FROM Ceiba pentandra $L$.}

\begin{abstract}
The randu caulis is a tropical tree belonging to the order Malvaceae (formerly Bombacaceae). The word 'kapok' is used to refer to the fiber produced from the seeds. This tree is also known as Javanese Cotton or Javanese Kapok. During this kapok caulis is only used as a plant or herbal medicine without being processed first. To provide information about secondary metabolites contained in the kapok stem Ceiba pentandra (L) Gaetrn. The method used is thin layer chromatography followed by column chromatography. Analysis of secondary metabolites by UV-Vis spectrophotometry with wavelengths of 200-600 $\mathrm{nm}$. The results of the study, it can be concluded that the kapok stem Ceiba pentandra (L) Gaetrn Contains flavonoid compounds with Flavon types.
\end{abstract}

Keywords: Thin Layer Chromatography, Column Chromatography, Stems, Staple Spectrophotometry $U V$-Vis 


\section{PENDAHULUAN}

Penggunaan bahan alam dibidang kesehatan maupun bidang lain seperti kosmetik hingga saat ini mulai meningkat, terlebih dengan adanya isu back to nature serta anggapan masyarakat terkait efektivitas dan keamanan produk herbal yang dianggap lebih menjamin dengan efek samping yang lebih ringan dibanding dengan produk sintetis. Hal ini mendorong penilitian tentang efektivitas tanaman obat terus meningkat dari tahun ke tahun (Gunawan dan Mulyani, 2004).

Batang randu diduga berpotensi memiliki kemampuan antibakteri dan memiliki kandungan senyawa bioaktif yang mampu menghambat pertumbuhan bakteri. Pada bagian kulit batangnya juga terdapat kandungan senyawa bioaktif seperti gula pereduksi (Doughari dan Ioryue, 2009), plobatanin, alkaloid, senyawa antrakuinon, saponin, glikosida (Anosike et al., 2012), tanin, fenolik, flavonoid, karbohidrat, resin, protein, minyak, steroid, dan terpenoid (Asare dan Oseni, 2012).

Banyaknya potensi yang dimiliki Batang Randu, dan dilihat dari latar belakang yang ada, maka penyusun akan mengangkat tema yang berjudul "Isolasi Metabolit Sekunder Flavonoid Dari Batang Randu (Ceiba pentandra( L) Gaetern.

\section{BAHAN DAN METODE}

\section{Prosedur Penelitian}

\section{Skrining Fitokimia}

Skrining fitokimia dilakukan terhadap serbuk simplisia. Skrinning fitokimia yang dilakukan yaitu uji alkaloid, triterpenoid, steroid, tanin, saponin, fenolik, dan flavonoid.

\section{Ekstraksi}

Pada penelitian ini, langkah awal yang dilakukan adalah pembuatan ekstrak batang randu. Metode yang digunakan adalah metode cara dingin yaitu meserasi, karena dengan cara ini dapat mencegah terurainya metabolit sekunder yang tidak tahan terhadap pemanasan. Proses meserasi di lakukan dalam waktu 24 jam ,meserasi yang dilakukan dengan metode bertingkat dengan pelarut n-heksana, etil asetat dan metanol. Kemudian hasil ekstrak disaring untuk memperoleh filtrat dan simplisia yang telah diekstraksi di lakukan remaserasi, kemudian hasil ekstraksi dipekatkan dengan evaporator. 


\section{Kromatografi Lapis Tipis (KLT)}

Uji KLT dilakukan terhadap ekstrak dan fraksi-fraksi yang didapat setelah perlakuan fraksinasi. Uji KLT dilakukan menggunakan sistem campuran eluen menggunakan pelarut n-heksan, etilasetat, metanol dan kloroform.

\section{Kromatografi Kolom}

Pemisahan dengan kromatografi kolom dilakukan dengan menggunakan rangkaian alat kromatografi kolom yang ditegakkan dengan statif. Kemudian sejumlah kapas dimasukkan ke dalam bagian paling bawah dari kolom, tidak terlalu padat atau terlalu longgar. Silika gel (fase diam) yang telah ditimbang didispersikan dalam n-heksan secukupnya. Silika gel yang telah basah atau seperti bubur dimasukkan dengan cara di pipet sedikit demi sedikit agar silika gel tersusun dengan rata di dalam kolom. Ekstrak kental yang sudah di campur dengan silika gel dimasukkan ke dalam kolom, kemudian ditambahkan pelarut pengembang ke dalam kolom sedikit demi sedikit. Hasil pemisahan ditampung dalam botol vial. Kemudian masing-masing fraksi pada vial diuji dengan KLT. Fraksi yang menampakkan bercak (dengan nilai Rf) yang sama dikumpulkan dan di diamkan supaya menguap.

\section{Kromatografi Lapis Tipis Dua Dimensi}

Pengujian ini dilakukan dengan menotolkan isolat aktif pada lempeng KLT dengan ukuran 6x6 cm kemudian di elusi pada arah 1 dengan eluen n-heksana - etil asetat (2:8) dan arah 2 dengan eluen yang sama.

\section{Uji Penampak Bercak}

Sitoborat

5 gr asam sitrat ditambahkan 5 gr asam borat dilarutkan dengan $100 \mathrm{ml}$ metanol, setelah itu plat disemprot lalu panaskan selama 5-10 menit.

Sianidin Tes

Serbuk $\mathrm{Mg}+\mathrm{HCl}$ pekat, terjadinya perubahan warna menunjukan bahwa adanya flavonoid.

\section{Identifikasi senyawa dengan Spektrofotometri UV-Vis}

Isolat yang diperoleh dari hasil KLT preparatif diidentifikasi secara kualitatif dengan spektrofotometri UV-Vis. Absorbansi senyawa flavonoid pada panjang gelombang maksimal. Pengamatan dilakukan pada panjang gelombang 200-400 nm dan 400- $800 \mathrm{~nm}$ 


\section{HASIL DAN PEMBAHASAN}

\section{Skrining Fitokimia}

Hasil skrining fitokimia simplisia batang randu (Ceiba pentandra( L) Gaetern dapat dilihat pada Tabel 1 bahwa batang randu positif mengandung metabolit sekunder Flavonoid, saponin, dan steroid.

Tabel 1. Hasil Pengujian Skrining Fitokimia Simplisia (Ceiba pentandra( L) Gaetern.

\begin{tabular}{lc}
\hline Metabolit Sekunder & Hasil Uji \\
\hline Alkaloid & - \\
Flavonoid & + \\
Saponin & + \\
Steroid & + \\
Polifenol & - \\
\hline
\end{tabular}

Keterangan :

$(+)$ : mengandung golongan senyawa

$(-)$ : tidak mengandung golongan senyawa

\section{Kadar Air}

Pada penelitian ini air yang tersuling sebanyak $0,4 \mathrm{ml}$ dan dilakukan perhitungan dengan hasil yang di dapat yaitu 1,6\% v/b. Hasil tersebut menunjukan bahwa serbuk daun randu Ceiba pentandra (L) Gaertn baik digunakan penelitian karena memenuhi persyaratan kadar air yang kurang dari $10 \%$. Penetapan kadar air ini bertujuan untuk memberikan batasan maksimum kandungan air di dalam sampel. Kadar air yang tinggi dapat menyebabkan pertumbuhan mikroorganisme yang akan mempengaruhi senyawa yang terdapat dalam sampel.

\section{Pengujian Kromatografi Lapis Tipis (KLT)}

Berdasarkan hasil KLT diperoleh beberapa bercak pada masing-masing plat dan dipilih nilai Rf yang baik dari ketiga ekstrak tersebut n-heksana B, Etil Asetat A, Metanol A,Metanol B dapat dilihat pada Tabel 2. 
Tabel 2. Hasil Pengujian KLT pada ekstrak n-heksana B, Etil Asetat A, Metanol A, Metanol B

\begin{tabular}{llll}
\hline Ekstrak & Kode & Warna Spot Noda & Nilai Rf \\
\hline n -heksana B & 2A & Biru & 0,6 \\
Etil Asetat A & 3A & Biru & 0,8 \\
Metanol A & 4A & Biru & 0,9 \\
& 4B & Hijau & 0,4 \\
& 4C & Merah & 0,3 \\
Metanol B & 4D & Biru & 0,1 \\
& 5A & Biru & 0,9 \\
& 5B & Hijau & 0,3 \\
& 5C & Merah & 0,2 \\
& 5D & Biru & 0,1 \\
\hline
\end{tabular}

\section{Kromatografi Lapis Tipis Dua Demensi}

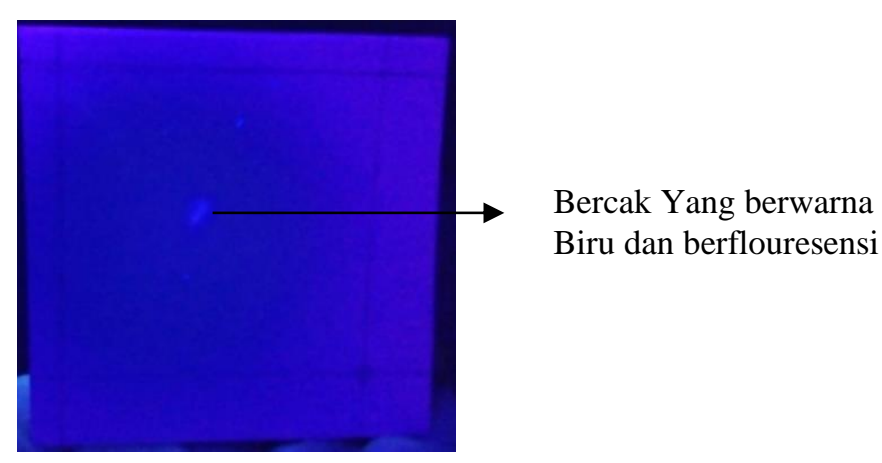

Gambar 1. Kromatogram pada EM2 hasil pemantauan KLT Dua Dimensi Dengan fase gerak n-heksana - Etil Asetat(2 : 8), Fase diam : silika gel GF 254.

Dilihat dari gambar diatas terdapat satu bercak terang yang dilihat di bawah lampu UV dengan keterangan 366 menandakan bahwa sample EM2 sudah murni dengan RF 0,5.

\section{Identifikasi senyawadengan Spektrofotometri UV-V is}

Fraksi yang diperoleh dari hasil KLT diidentifikasi dengan spektrofotometri UV-Vis digunakan untuk mengetahui nilai absorbansi senyawa pada panjang gelombang maksimal. Pengukuran spektrum dilakukan pada panjang gelombang 00-600 nm. Spektrum khas flavonoid terdiri atas dua pada rentang 230-290 (pitaII) dan 300-560 nm (pita I). Adapun rentang serapan spektrum UV-Vis tampak flavonoid dapat dilihat pada Tabel 3. 
Tabel 3. Rentang Panjang Gelombang senyawa Flavonoid (Markham,1988)

\begin{tabular}{|c|c|c|}
\hline Pita II (nm) & Pita I (nm) & Jenis Flavonoid \\
\hline $250-280$ & $310-350$ & flavon \\
\hline $250-280$ & $330-360$ & $\begin{array}{l}\text { Flavonol (3-OH } \\
\text { tersubsitusi) }\end{array}$ \\
\hline $250-280$ & $350-385$ & Flavonol (3-OH bebas) \\
\hline $245-275$ & $\begin{array}{l}310-330 \text { bahu kira- } \\
\text { kira } 320 \text { puncak }\end{array}$ & Isoflavon \\
\hline $275-295$ & 300-330 bahu & $\begin{array}{l}\text { Flavanon dan } \\
\text { dihidroflavonol }\end{array}$ \\
\hline $230-270$ & $340-390$ & Khalkon \\
\hline $\begin{array}{l}\text { 230-270 (kekuatan } \\
\text { rendah) }\end{array}$ & $380-430$ & Auron \\
\hline $270-280$ & $465-560$ & $\begin{array}{l}\text { Antosianidin dan } \\
\text { antosianin }\end{array}$ \\
\hline
\end{tabular}

Seyawa flavonoid golongan flavonon menurut markham (1988) "memberikan rentang serapan pada panjang gelombang $275-295 \mathrm{~nm}$ pada pita II dan 300-330nm (bahu) pada pita I, hasil analisis menggunakan Spektrofotometri UV-Vis yang dilakukan Markham dapat dilihat pada Gambar 2".
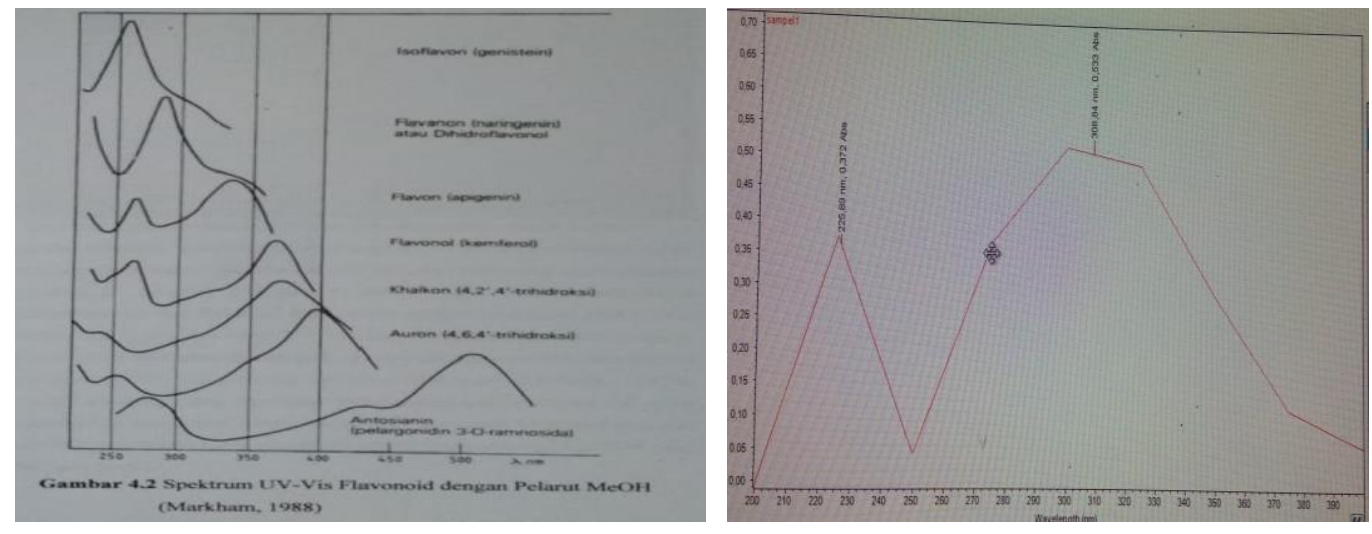

Gambar 2. Perbandingan Spektrum UV-Vis Flavonoid Menurut (Markham,1988) dengan Hasil Spektrofotometri UV-Vis Ekstrak Metanol Batang Randu.

Hasil analisa menggunakan spektrofotometri UV-Vis pada senyawa EM2 menghasilkan $\lambda$ maks pada daerah 225 (pita II) dan 308 (pita I). Hasil spektrum yang di peroleh diduga batang pohon randu (Ceiba pentandra L.) ini mengandung senyawa flavonoid golongan Flavon hal tersebut diperlihatkan dengan bentuk spektrum yang hampir sama dengan spektrum Flavon yang terdapat dalam pustaka. Gambar spektrum UV-Vis hasil kolom (dalam EM2). 
Senyawa metabolit sekunder tersebut juga di perkuat dengan dilakukan uji kualitatif dengan uji skrining fitokimia, sianidin tes, dan penampak bercak. Dimana tujuan dilakukan skrining fitokimia ini adalah untuk membuktikan fraksi tersebut merupakan senyawa flavonoid berdasarkan reagen yang tepat. Fraksi yang digunakan untuk uji spektrofotometri UV-Vis diuji dengan penambahan metanol, serbuk Mg dan 0,5 ml HCL lalu dikocok kuat, adanya larutan yang berubah warna menjadi kuning merupakan positif mengandung senyawa flavonoid (Herborne,10978). Penampak noda sitroborat yang digunakan untuk mendeteksi senyawa flavonoid dengan menunjukan warna biru terang. Hasil pada batang randu (Ceiba pentandra L.) menunjukan positif mengandung flavonoid.

\section{KESIMPULAN}

Berdasarkan hasil penelitian, dapat disimpulkan bahwa pada batang randu (Ceiba pentandra (L) Gaertn di duga Mengandung senyawa golongan flavonoid dengan jenis Flavon.

\section{DAFTAR PUSTAKA}

Shahidi, F., Kadaswarmi, C., Middleton, E., Shukla, V.K.S. Natural Antioxidants: Chemistry, Health Effects, and Applications, AOCS Press, Illionis, 1997.

Khanahmadi, M., Rezazadeh, S.H., Taran, M. In vitro antimicrobial and antioxidant properties of Smyrnium cordifolium boiss. (Umbelliferae) extract, Asian Journal of Plant Sciences, 2010; 9 (2), 99-103.

Leong, L.P., and Shui, G. An investigation of antioxidant capacity of fruits in Singapore markets. Food Chemistry 2002; 102:732-737.

Mayer, Alejandro, M.S. et al. Marine pharmacology in 2007-8: Marine Compounds with antibacterial, anticoagulant, antifungal, anti-inflammatory, antimalarial, antiprotozoal, antituberculosis, and antiviral activities; affecting the immune and nervous system, and other miscellaneous mechanisms of action. Elsevier Inc. Part C, 2010. 1191-222.

Molyneux, P. The use of the stable free radicals diphenylpicrylhydrazyl (DPPH) for estimating antioxidant activity. Songklanakarin Journal of Science Technology, 2004; 26(2), 211-219.

Romansyah, Y. Kandungan Senyawa Bioaktif Antioksidan Karang Lunak Sarcophyton sp Alami dan Transplantasi Di Perairan Pulau Pramuka, Kepulauan Seribu. Bogor: Institut Pertanian Bogor. 2011.

Sunardi, K.I. Uji Aktivitas Antioksidan Ekstrak Belimbing Wuluh (Averrhoa blimbi, L) Terhadap 1,1Diphenyl-2-Picrylhidrazyl (DPPH), Seminar Nasional Teknologi, 2007. 1-9. 
Veron, J.E.N. Corals in Space and Time. The Biogeography and Evolution of the Scleractinia. UNSW Press. 1995.

Winarsih, H. Antioksidan Alami dan Radikal Bebas. Yogyakarta: Kanisius. 2007. 